has not had the same attention lavished on it as has been given to the more historic epochs of the Leonids, Lyrids and Perseids. Vet occasionally, even when only moderately active, the Quadrantid Radiant furnishes displays of about 40 meteors per hour. In the year 1839 Herrick drew attention to the recurring character of a meteor shower on January 2. A stimulus was given in the same direction when in 1839 Quetelet published his valuable contribution to me teoric literature in his " Catalogue des Principales Apparitions d'Etoiles Filantes," in which were cited two instances when meteors were reported to have been unusually numerous on the morning of January 2 , vir. in 1835 and $183^{8}$ There was also a previous account of the appearance of an extraordinary bolide in the north of Italy in the year 1825 , on the morning of January 2 at 5 o'clock, before and after which hour on that night there was noticed a great abundance of meteors.

When Quetelet published a second edition of his work a few years later it contained motices of Quadrantid displays on the same day of the month in the intervening years I 839 and 1840 Their observation in those years, however, may have been due to their having been specially looked for. The next notable display occurred in I862, and was accidentally witnessed on the morning of January 2, between about 4 and 5 o'clock, by a lady residing in Harford, Connecticut, U.S., who on this occasion seems to have had the honour of being the sole observer of the apparition. Her attention was attracted by a luminous cloud moving from west to east, and also by the appearance of fine meteors at the rate of about three per minute. Two years later there occurred" another display in England, on the night, however, instead of the morning of January 2 , for which an organised watch had been kept. Profs. Herschel and Gregg (British Association Report, 1864, p. 30) each observed fifty shooting stars from different stations during the hours to to 12 p.m. and Io to I respectively, while another observer, Mr. W. H. Wood, reckoned that the Quadrantids were appearing at the rate of one per minute during the hours 12 to 2 . Prof Kirkwood, who instituted researches respecting the periodicity of these meteors and also of other meteor-systems, showed in a paper read before the American Philosophical Society in 1873 that the Quadrantid maximum recurred every thirteen years, the principal displays having taken place in 1825, 1838 and 1864 . The intervening maximum between the two last dates is supposed, of course, to have passed unnoticed.

The expected shower, however, in 1877 was looked for in vain owing to unfavourable weather, but on the morning of January 2 in the following year, during a brief interval of clear sky beginning at 4 o'clock, Prof. Herschel noted the appearance of seventeen Quadrantids, nearly half of which ranged in brightness from the brilliancy of Sirius to that of second magnitude stars. Weaker apparitions from the Quadrantid radiant also occurred on the nights of January 2 in the years 1872 and I873, but seem to have been only partially or imperfectly observed. The circumstance that the principal appearances of these meteors evidently took place in $1825,1838,1862$ and 1864 , and (probably) also in 4878 naturally leads to the expectation that another fine display may be observed in I9O2. An examination of the dates at which the first three of these showers occurred shows that the Quadrantid meteoric epoch is gradually, as in the case of other well-known star showers, advancing into the year. The advance takes place on the average, however, and is not very noticeable over short periods, being warped by Auctuations in the date of the shower's appearance with respect to the mean date, such fluctuations being produced by the perturbations which occur in the meteoric orbit.

The display in America in the year 1862 and also those on the night of January 2 in 872 and I 873 illustrate this advance. A calculation made by the writer with such data as the above displays afford shows that the time of the next shower's expected appearance falls on the night of January 4 in 1902 , the maximum or centre of the display being due at $3 \mathrm{~h}$. $30 \mathrm{~m}$. on the morning of the 5th. Earlier in the night, shortly after 12 o'clock, meteors will probably be unusually numerous. The display in 1864 evidently did not attain the brilliancy of the previous displays. Calculation shows that the maximum of this shower occurred about Io p.m. on the night of January 2 , which prevented the shower being fully observed. Probably some early Quadrantids of the expected display will appear on the morning and also early on the night of January 3. The lateness of the maximum on the night of January 4 is more apparent than real, owing to 1900 not being a leap year. JOHA R. HENRY.

\section{Frost Patterns in Mud}

ON many oecasions recently frost patterns in mud have been exceptionally well marked, similar to those formerly described by Prof. Bonney and others- (see Nature, vol. lxiii. p.. 347; Proc. Roy. Soc, nol. lxiii. p. 217).

On December 15 several of the usual forms were to be seen, the patterns generally being rather coarse, buti elaborate, having branehed and curving axes.

Thus, (I) ion many ordinary flagstones the ice-fromds spreat from the centre outwards, over a patch, roughly oval on an oblong stone, roughly circular on a square one, leaving bare a space towards the edge ; although sometimes radial or branched forms stanted from the edge in addition. (2) The centre of the pattern on some flagstones was occupied by a lumpy mass. This consisted of frozen mud, sometimes having a:border two to three inches wide formed of i scattered separate lumps. . (3) One example, however, was rather exceptional.. On a.concrete path in St. Jiames's Park a space of a few square yards was broken into patches (from a few inches to 2 :feet or more- in diameter) with outlines roughly hexagonal or partly curved, resembling the ends of basalt columns. In these patches the branching frost-fronds had spread from the centre outwards, while, between the patches, a space about $\frac{1}{2}$ inch broad was clear of ice. This example reminded me of the spheroids with attempts at spherulitic or variolitic structure in various igneous rocks (see Q.J.G.S. vol, xlix. p. I55); and here also one asks whether the contraction which caused such jointing was favourable to crystallisation, or did the crystallisation from a ce ntre cause the contraction, or were the two independent though they cooperated to produce the general result?

Catherine. A, Raisjon.

\section{THE ROYAL COMMISSIOM ON COAL RESOURCES.}

THE announcement that a Royal Commission has been appointed to inquire into the coal resources of the United Kingdom had not been anticipated by: public opinion. Yet, in view of the articles on the subject published in NATURE (I897; p . 389, and 1900; p. I 24), it should hardly give occasion for surprise. The duration of the British coal supplies is a question that has lost none of its interest since the previous exhaustive inquiry conducted in $1866-1871$ by the Royal Commission of which the late Duke of Argyll was chairman. . The fifteen Royal Commissioners - all of whom, with one exception, have now passed away-were: among the most eminent men of their day, and their calculations were carried out in a thorough and complete manner. In the course of thirty years, however, unexpected changes have taken place in the coal trade. The annual output of coal in the United Kingdom thirty years ago was not more than $100,000,000$ tons; it now exceeds $225,000,000$,tons, and the process of exhaustion still continues. The beginning of the twentieth century is evidently an opportune time for taking stock of the national resources of the mineral on which so much of the prosperity of the country depends. The new inquiry is to be: of a far-reaching character. The terms of reference are as follows :-

To inquire into-(I) The extent and available resources of the coalfields of the United Kingdom ;. (2) the rate of exhaustion which may be anticipated, having regard to possible economies in use by the substitution of other fuel or the adoption of other kinds of power; (3) the effect of our export of coal on the home supply and the time for which that supply, especially of the more valuable kinds of coal, will probably be available to British consumers, including the Royal Nasy, at a cost which would not be detrimental to the general welfare; (4) the possibility of a reduction in that cost by cheaper transport, or by the avoidance of unnecessary waste in working through the adoption of better methods and improved appliances, or through. a change in the customary term and provisions of mineral leases; and 
(5) whether the mining industry of this country under existing conditions is maintaining its competitive power with the coalfields of other countries.

The chairman of the Commission is the Right Hon. W. L. Jackson, M.P., chairman of the Great Northern Railway Company, and he has fifteen colleagues. Coal-mining interests are represented by Sir W. T. Lewis, the eminent South Wales colliery owner, Sir Lindsay. Wood, chairman of the Durham Coal Trade Association, Mr. A. C. Briggs, of Normanton, Yorkshire, Mr. J. S. Dixon, the Scotch coalmaster, president of the Institution of Mining Engineers, Mr. A. Sopwith, of Cannock Chase Colliery Company, and Dr. C. Le Neve Foster, F.R.S., professor of mining at the Royal College of Science and Royal School of Mines. The working men's interests are entrusted to Mr. W. Brace, of the South Wales Miners' Federation, and Mr. R. Young, of the Northumberland Miners' Association. Transport interests are in the hands of Sir G. J. Armytage, chairman of the Lancashire and Yorkshire Railway Comıany, of Mr. Thomas Bell, coal exporter of Newcastle-on-Tyne, and of Mr. J. P. Maclay, shipbroker, of Glasgow. Geology is represented by Mr. J. J. Harris Teall, F.R.S., Director-General of the Geological Survey, by Prof. C. Lapworth, F.R.S., of Birmingham Úniversity, and by Dr. E. Hull, F.R.S., formerly Director of the Geological Survey of Ireland, whilst chemistry is represented by Prof. H. B. Dixon. F.R.S., of Owens College, Manchester.

The main interests involved are thus represented with the exception of the consumers. The metallurgical industries, which consume such vast quantities of British coal, do not find their spokesmen on the Commission. This is a matter of regret, inasmuch as metallurgy was so largely represented on the previous Commission; and the investigations of Sir Hussey Vivian, Dr. Percy, Mr. Hartley of Wolverhampton, and Mr. G. T. Clark of Dowlais, on waste in combustion were amongst the most valuable of the results of the Commission.

The task of the Royal Commission to estimate the available resources of the British coalfields is one of great difficulty, and it is to be feared that any estimate must be of slight value, owing to the impossibility of prophesying with accuracy either the rate of increase in production and consumption, or the limits at which mining may be carried on with profit. Prof. Hull, one of the Commissioners, has already published a reassuring estimate, although it is not in accord with the less optimistic and divergent views expressed by Prof. Stanley Jevons, by Mr. Leonard H. Courtney, by Mr. R. PriceWilliams and by Mr. T. Forster Brown. The questions of the possible economies in the use of coal and of the adoption of better methods of working should prove the most frutful field for the Commission's labours. Great Britain now produces one-third of the world's supply of coal ; and more and more attention is being devoted to improvements in mining details. Although the use of mechanical coal cutters has by no means become as general as it has in the United States, where 25 per cent. of the output is thus obtained, there has recently been a distinct increase in the use of these labour-saving appliances. Moreover, endeavours are being made to economise in the consumption of coal, notably in the South Staffordshire coalfield, where the producer-gas invented by Dr. Ludwig Mond has recently been introduced as a cheap source of heat and power. That great economies in the home consump tion of coal have been effected since 1871 is unquestionable. Indeed, Mr. Price-Willams has shown that, whereas in 1871 the iron and steel trade required 30 per cent. of the coal consumed in the United Kingdom, its requirements had been reduced to 16 per cent. at the time he read his paper before the Statistical Society in 1889. To further coal economies effected in the manuNO. I679, vOL. 65$]$ facture of iron and steel Mr. Bennett Brough has drawn attention in an article on the scarcity of coal in the Nineteenth Century (April, 1900). There is, however, still room for large economies in coal in the manufacturing industries; and the results of a searching inquiry into the subject cannot fail to be of permanent value and interest.

\section{ON PAPER AND PEROXIDE OF HYDROGEN.}

DESIRE to show by means of the following photographs some special points of interest which occur when certain papers are allowed to produce pictures on a photographic plate in the dark. Some papers are themselves active, that is, if they be simply placed on or near to a photographic plate in the dark they act upon it so that after ordinary development a picture is produced. Other papers which are without this power can be examined by placing them on a photographic plate and putting behind them a plate which is giving off hydrogen peroxide, such as one of plaster of Paris or a pad of blotting-paper which have been soaked in an aqueous solution of this body, or a plate of polished zinc, or a piece of cardboard or glass which has been painted over with copal varnish or other body of that kind. There is also with regard to paper the action of writing and printing ink upon it.

The fibres which are used in paper making are ${ }^{1}$ cotton, flax, hemp, wood celluloses, esparto, straw celluloses,

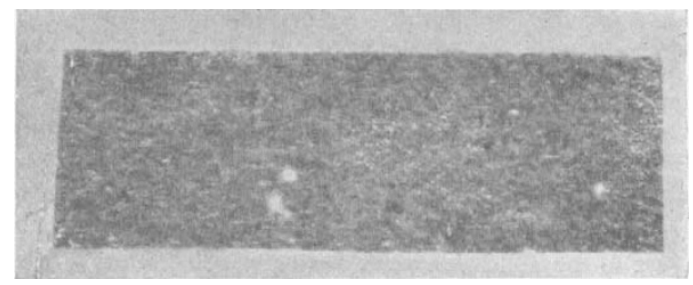

FIG. I.

mechanical wood pulp. Of these bodies cotton and hemp are entirely without action on a photographic plate; all the other materials are more or less active, especially so is mechanical wood pulp and flax. If, however, any of these bodies, even the most active, be bleached, they lose this activity; the bleaching must, however, be very complete to destroy altogether their activity, and many papers although bleached are still active. On the other hand, the activity of a paper may arise, not from the paper itself, but from the size which has been added; this occurs when rosin is used.

The ordinary first-class papers are entirely without action on a photographic plate, but the common kinds are generally active. For instance, we may take some of the daily newspapers as illustrating this. The following results apply to copies issued on November 25, 1901 : the Standard, Daily Express and Daily Mail all gave a dark picture, the Pall Mall a good, but not so dark a picture as the former papers; the Westminster and the Sportsman gave a faint picture, and the Times, Globe and NATURE only very faint pictures, and, lastly, the Daily Telegraph, Daily News, Daily Graphic and Morning Leader gave no picture at all. Punch paper is also not active.

With books and periodicals the least expensive are usually the most active; as far as I am aware the paper of high-class books is without action on a photographic plate. Fig. I is a picture produced by an active paper. 1 Report on the Deterioration of Paper, Society of Arts. 